\title{
A construção do Uno ${ }^{1}$
}

\author{
The construction of the One God
}

\section{Haroldo Reimer}

Doutor em Teologia pela Kirchliche Hochschule Bethel (Alemanha), Teólogo luterano, professor na Pontifícia Universidade Católica de Goiás (PUC-Goiás), Universidade Estadual de Goiás (UEG), bolsista de Produtividade em Pesquisa do CNPq, Goiânia, GO - Brasil, e-mail: haroldo.reimer@gmail.com

\section{Resumo}

0 artigo trata de indicar alguns elementos do processo de formação da ideia ou da concepção de um Deus Uno como expressão identitária dominante na cultura oficial do antigo Israel. 0 texto apresenta inicialmente, de forma panorâmica, alguns aspectos da história do antigo Israel para, a seguir, alocar nestes momentos os prováveis passos para a construção do ideário monolátrico e monoteísta do antigo Israel.

Palavras-chave: Monoteísmo. Tradição. Identidade religiosa. Poder. Antigo Israel.

\section{Abstract}

The present paper aims to show some elements of the formative process for idea or concept of a One God as dominant identity expression in the official culture of ancient

1 Texto vinculado com o projeto de pesquisa Militarismo, cultura e religião no antigo Oriente Próximo, desenvolvido junto a Unicamp como atividade de pós-doutoramento sob a supervisão do Prof. Dr. Pedro Funari. 
Israel. The paper begins with a panoramic presentation of some aspects of the history of ancient Israel. In a second moment, it allocates the likely steps of the building of the monolatrous, monotheistic ideas of ancient Israel to those moments.

Keywords: Monotheism. Tradition. Religious identity. Power. Ancient Israel.

\section{Introdução}

A construção da ideia da existência de um Deus Uno entendido como criador do cosmo e responsável pelos mais diferentes âmbitos da existência individual e coletiva é decorrente de um longo e multifacetado processo na história do antigo Israel, com algumas influências do seu entorno cultural. Trata-se aí do processo de construção do sistema religioso e cultural chamado de monolatria ou monoteísmo hebraico. Para entender este processo, alguns apontamentos de ordem histórica se fazem necessários.

\section{Apontamentos de ordem histórica}

O antigo Israel é uma formação social, cujas origens historicamente acessíveis remontam às áreas montanhosas da terra de Canaã na transição do período do bronze recente para a época do ferro (séc. XV-XII a.C). A estela de Merneptah é o documento extrabíblico mais antigo a fazer referência a este Israel. Em decorrência de fatores sociais e políticos diversos, entre eles o enfraquecimento do controle egípcio sobre a região da planície costeira e o domínio parcial de novas tecnologias (ferro e cal), grupamentos humanos de origem étnica e social diversificada constituíram povoamentos nos rincões montanhosos distantes do controle do poder das cidades-estado nas regiões de planície.

Sobre a forma de vida e de organização dessa gente, obtemos informações a partir de textos da Bíblia, os quais, após acurada análise histórico-crítica, podem ser usados como fonte histórica. Mas não podem ser fonte única. Os resultados das muitas escavações arqueológicas são 
outra fonte importantíssima, pois os restos materiais de uma cultura com sedimentações sobrepostas num mesmo lugar deixam traços e vestígios, que devem ser justapostos criticamente ao material epigráfico, incluindo os textos bíblicos. Os resultados arqueológicos podem e devem ser um elemento de suspeita e de controle acerca de intencionalidades de textos bíblicos em seus momentos de emergência.

Os grupamentos originários do antigo Israel nas montanhas de Canaã constituíram formas de associação entre si, experimentando diferentes graus de sedimentação institucional. Ao longo de todos os séculos, as relações de parentesco desempenharam um papel fundamental, funcionando como a base da sociedade. Associações mais amplas podem ter dado origem a estruturas tribais ou mesmo a ligas tribais de alcance geográfico limitado. Os primeiros dois séculos da existência desse antigo Israel nas montanhas provavelmente estiveram marcados por uma existência tribal (chiefdom), com associações esporádicas entre tribos para suprir necessidades momentâneas, como, por exemplo, a defesa ou a guerra (KESSLER, 2009, p. 66-78). Sobre essa forma de existência falam os textos bíblicos, não havendo argumento arqueológico explícito em contrário.

A partir do século X a.C., a estrutura tribal foi suplantada pelo estabelecimento de estruturas de ordem estatal e monárquica. A partir constituiu-se um "estado primitivo" (KESSLER, 2009, p. 81). Informações bíblicas sobre um "estado no campo de batalha", a exemplo das peripécias de um líder tribal como Saul ou sobre uma consolidação de tais relações sob um líder do tipo mercenário como Davi, devem ser levadas em conta para a reconstrução do processo de constituição da monarquia sob Davi. Alguns arqueólogos, a exemplo de Israel Finkelstein, têm insistido no fato de que não há porque duvidar da existência de uma monarquia davídica na região montanhosa de Judá, muitos menos que Davi, com uso de astúcia, tenha conquistado a cidade jebusita de Jerusalém no século X a.C. (2 Sm 5,6-10), transformando-a na capital de seu reino (OTTO, 1980). O tópico discutível é se houve historicamente um "império davídico-salomônico" como é descrito pela Bíblia. Essa informação pode tratar-se de uma reconstrução mítica de tempos posteriores, provavelmente da época de governo do rei Josias, no século VII a.C., após a retirada dos assírios como força imperial de ocupação em toda a região ao longo de vários 
séculos e em meio aos anseios de construção de um reino com a inclusão ou conquista dos territórios "abandonados" pelos assírios na parte norte da região. O “império" de Davi e de Salomão provavelmente foi muito mais modesto e circunscrito, a julgar pela extensão da capital Jerusalém conforme informam os dados arqueológicos a respeito. Provavelmente tratou-se somente de um reino periférico no contexto geopolítico do antigo Oriente próximo. Ao invés de tal "império unido", seja historicamente mais fundado trabalhar com a hipótese de que, a partir das estruturas tribais regionais, tenham sido estabelecidos desde o início dois reinos distintos, um no norte, nas serras férteis de Efraim, e outro no sul, nas serras áridas de Judá. Apontamentos das crônicas reais, compiladas nos Livros dos Reis, dão suporte a essa ideia, embora a perspectiva de exposição da narrativa sempre seja a partir de Judá, espaço no qual as tradições fundantes do antigo Israel foram amalgamadas na forma de textos autoritativos no período final da monarquia e especialmente no período do pós-exílio.

Pela própria situação geográfica, com maior presença de recursos hídricos e solos mais férteis, o norte provavelmente sempre foi mais rico e mais poderoso. Mas o sul assumiu a tarefa de formatar as tradições com projeções e intencionalidades, que nem sempre são claramente identificáveis na superfície dos textos bíblicos. No seio dessas formas de organização diferenciadas, foram criados traços e laços identitários que foram capazes de outorgar identidades regionais e distintas, apesar de traços culturais comuns. Na forma final dos textos da Bíblia hebraica, predomina a construção identitária feita por meio das condições e da perspectiva a partir do reino de Judá. A Bíblia hebraica está marcada por uma visão tendencialmente negativa em relação à história e à identidade da formação social do reino do norte. Especialmente a dimensão religiosa do norte reiteradamente é apresentada sob um viés negativo, manejando-se termos como apostasia, "fazer o que é mau", etc (2Rs 17). Há que se reconhecer que, para formações sociais do antigo Israel, o que chamamos de religião constitui um elemento essencial na constituição da identidade.

Nos diferentes momentos da história dos antigos hebreus, houve promoção de traços identitários. Isso se dava nas tribos, mas em especial também nos reinos (norte e sul), cada qual com suas idiossincrasias. Sobre a identidade própria do reino do norte não há muitas informações 
disponíveis; as informações existentes passaram por releituras no sul, em Judá. Tradições e textos são relidos à luz de novas demandas. $\mathrm{Na}$ Jerusalém de Davi e de Salomão, nas proporções modestas de um reino periférico nas montanhas, com uma capital com no máximo quatro hectares (OTTO, 1980), o funcionalismo da corte e os sacerdotes do templo constituíam atores importantes para a formatação da chamada "tradição de Sião". A noção de que Jerusalém é um lugar de habitação da paz (Is 1,21-16) ou que é inexpugnável por conta da presença do Deus YHWH no santuário central são apenas elementos de uma tradição com muitas ramificações. Eventos históricos, como a frustrada tentativa de ocupação pelos assírios em 701 a.C. podem ter sido utilizados para incrementar tal projeção ideológica da cidade. Acompanhado da imagem da cidade idealizada produz-se também uma ideologia régia, como era comum em todos os reinos e impérios da Antiguidade oriental. A ideologia real cultivada em Jerusalém apresentava traços similares a outras projeções deste tipo, evidenciando também o intercâmbio de tradições e produtos culturais entre os reinos no crescente fértil. O antigo Israel é produtor e especialmente também receptor de tais tradições, devidamente adaptadas aos contornos geográficos e históricos. Muitas tradições mesopotâmicas e egípcias foram recepcionadas e adaptadas. Cerimônias oficiais na capital do reino podem ter servido como lugar vivencial para a formatação de tradições reais, como transparece ainda em salmos reais (S1 2; 72; 110).

Na história do antigo Israel, o momento mais favorável para a produção de identidade nos termos do que hoje poderíamos chamar de 'nacional' se dá na segunda metade do século VII a.C., quando, com a retirada dos assírios como força de ocupação, a partir de 640 a.C., se dá uma espécie de 'vácuo de poder'. Como em termos conceituais não existe vácuo de poder, nesse período se constituem novas relações de poder com ênfase na reorganização interna de Judá. O conjunto dos eventos desse período usualmente é manejado no contexto da chamada 'reforma josiânica' (2Rs 22-23), a qual, na literatura especializada, é avaliada sob perspectivas muito distintas. Após a destruição do reino do norte, em 722 a.C., o provável desmantelamento interno das forças políticas na região norte, em decorrência de sucessivos e sangrentos golpes de Estado (2Rs 15) e o repovoamento da região da antiga capital Samaria por contingentes 
populacionais assírios, é o reino de Judá nas montanhas de Judá que ascende como herdeiro e formatador das tradições hebraicas que passaram a dar suporte identitário para um Israel unido. Nesse processo, há projeções idealizantes que, contudo, não estão totalmente descoladas das condições históricas reais. Assim, por exemplo, a 'descoberta' e formatação de um livro de leis (2Rs 22,8), como é projetado para o livro de Deuteronômio, pode perfeitamente ter tido lugar nesse momento histórico no fim do século VIII a.C. Pode-se trabalhar com o dado de que, certamente com apoio em experiências e tradições anteriores, nesse momento se buscou formatar a identidade o novo Israel com o recurso a textos de caráter oficial. A edição de conjuntos de normas e de leis, por ocasião da ascensão de um novo governante ao poder ou no início de seu governo, faz parte da tradição vétero-oriental comum, sendo Hamurábi o exemplo mais ilustre. Josias foi filho de um novo momento histórico e soube aproveitar com grandeza e inventividade as chances do momento.

Todo o conjunto de ações no contexto da chamada 'reforma político-religiosa' de Josias indica para a construção de uma nova tessitura das relações sociais em Judá. As relações de parentesco e de política matrimonial entre a capital e o interior certamente fortaleceu a posição das famílias proprietárias, criando também normatizações ético-legais para redes mínimas de solidariedade para com os segmentos sociais empobrecidos, tão bem elaboradas nas leis sociais do Deuteronômio (CRÜSEMANN, 2002). Especialmente as ações de centralização de culto em Jerusalém e o fechamento dos santuários do interior reforçaram as condições de circulação de bens na economia em Jerusalém, criando as condições para a reiterada submissão de boa parte do povo como leitor-ouvinte de produções mítico-históricas destinadas para a intervenção social. Exemplo disso é a proposta contida no livro de Deuteronômio para que o teor da obra seja recitado publicamente nas grandes festas ao longo do ciclo anual de festas e peregrinações ao santuário central (Dt 6; 11), eventualmente em cerimônias públicas de aliança, ajudando, assim, a criar um traço teológico que se torna marcante somente a partir desse período, a chamada 'teologia da aliança'. De uma forma mais marcante, no reinado de Josias, a teologia da aliança é um instrumento importante para a formatação de uma 'identidade nacional'. O sacerdócio oficial do templo central 
desempenhou papel de protagonista nessa construção. Assim, com a gradativa centralização das ações cultuais na capital, houve as condições para a proclamação programática da existência de um único Deus da nação de Israel-Judá. A diversidade religiosa, por exemplo, o culto a Baal, a Aserá e ao panteão celeste, passou a ser tabuizada e combatida nos limites de uma espécie de 'guerra santa' contra práticas religiosas populares e desviantes do credo oficial. Elementos militantes dessa construção transparecem, por exemplo, em tradições relidas e (re)formatadas nesse período, como a tradição de Elias (1Rs 17-2Rs 2), tido como o fundador histórico-mítico do zelo monoteísta. O livro de Deuteronômio também está repleto de tais trechos fortemente militantes e delimitadores. Memórias proféticas também são relidas e cooptadas para essa finalidade, como, por exemplo, textos e tradições relativas ao profeta Oseias, um batalhador pela monolatria. Suas palavras foram substancialmente aproveitadas no processo de centralização cultual em Jerusalém no período de Josias.

As reinvestidas estrangeiras sobre o pequeno território de passagem de Canaã ou Israel marcaram um fim rápido do processo de reorganização sob Josias. Os egípcios buscaram reaver seu antigo Hinterland, fazendo expedições militares na região da planície costeira, com o objetivo último de firmar fronteiras em face do avanço dos babilônios, um novo grupo mesopotâmico a assumir o lugar dos assírios a partir do fim do século VII a.C. O rei Josias foi morto pelo faraó Neco em Megido (2Rs 23,28-30). Com sua morte, o projeto de um Israel forte e até imperial caiu por terra, abrindo caminho para nova dominação estrangeira na região. Depois de Josias, houve ainda alguns governantes, em geral subalternos aos babilônios, embora com alguns ensaios de resistência que culminaram em sítios, conquistas, mortes e deportações. Vários exílios marcaram a existência de Israel nas primeiras décadas do século VI a.C. Vivências em terras estrangeiras serviram para fortalecer identidades por dois caminhos: o fortalecimento das tradições próprias e a integração seletiva da cultura dominante babilônica e, depois, persa.

No período da dominação persa, no século $V$ a.C., se constituem propriamente as bases do Judaísmo. Sobre uma área geográfica muito mais limitada, é organizada a província persa de Yehud a partir de territórios subtraídos por concessão persa à província de Samerina. Sobre 
o espaço do Yehud pós-exílico, dão-se os movimentos mais importantes para a constituição dos traços identitários mais marcantes o Israel antigo. O templo é reconstruído, a cidade é reerguida e fortificada, e o governo é assumido pelo revezamento de elites sacerdotais. Tudo isso se dá nos marcos da chamada 'política de tolerância' dos persas, os quais, na sua estratégia de dominação, permitem a reorganização cultural e religiosa dos povos dominados. Além da reconstrução do templo, nesse período é composta e estabelecida a Torá como estandarte identitário o Israel pós-exílico (CRÜSEMANN, 2002). No núcleo da Torá estão contidas memórias de tradições de fé em YHWH, de diferentes recortes, agora formatadas numa moldura maior para dar sustento à ideia ou à concepção de um Deus Uno afirmado como responsável pelos diversos âmbitos da vida e da história.

\section{A construção do Uno}

A construção do Uno é um processo complexo e multifacetário, que se estende por séculos, para edificar a ideia ou a concepção da existência de um só Deus, o qual é responsável pelos diferentes âmbitos da vida humana e da história natural. Esse processo teve seus inícios no fim do segundo milênio chegando a sua maturidade no século $\mathrm{V}$ a.C. na pequena província de Yehud, terreno árido no qual nasceu aquilo que conhecemos como o judaísmo originário. "Eu sou o primeiro e o último, e além de mim não há Deus" (Is 44,6) é uma fórmula que resume o resultado final da concepção do Deus de Israel. O Uno, só, anicônico, exclusivo, masculino, onipotenciário, justo e defensor dos pobres - tudo isso são marcas distintivas desse Deus de Israel, confessado e recitado como o Uno nas palavras do shema yisrael (Dt 6,4). Com essa concepção, foram lançados alguns dos fundamentos do mundo Ocidental.

A construção da ideia do Uno inicia em meio a um contexto politeísta. A região do Levante, ao fim do segundo milênio e nos primeiros séculos do primeiro milênio, era um mundo politeísta em termos de representação das divindades. Em Canaã, o Deus El era celebrado como o chefe do panteão divino; no imaginário divino, era ladeado por Astarte, sua consorte divina; Baal assumiu, a partir de certo momento, posição de 
protagonista divino. Muitos rituais e textos míticos celebram a atuação dessa representação divina, especialmente em festivais de fertilidade. A pluralidade das representações divinas cananeias era consoante com o que se passava na Mesopotâmia. Apesar da dominância de Marduque, havia a representação de todo um panteão. $O$ casal divino com sua descendência era um traço comum também no Egito, com Orisis, Íris e Horus.

No espaço e no tempo do antigo Israel, há um desenvolvimento próprio, diferenciado. A existência de um Deus nacional como é afirmado especialmente na teologia deuteronômica, que assume traços da teologia de Sião, cultivada em Jerusalém pelo sacerdócio no templo, é algo que existe também nos povos do entorno do antigo Israel. Os moabitas celebravam a Quemosh ou Camos como sua divindade nacional. Em Israel, YHWH é afirmado e celebrado nessa posição.

Segundo as tradições bíblicas, o Deus YHWH não era uma divindade "autóctone" da região de Canaã. Ele vem de fora, de regiões do deserto. A tradição dominante no Pentateuco o situa no Sinai, cuja localização no atual Monte Sinai, na homônima península data do século IV d.C. (Ex 19). Esse monte distante é o lugar mítico da origem de toda a legislação hebraica. Outros textos, com fragmentos de memórias de tradições antigas, remetem também para o ambiente desértico e periférico (Hc 3; Jz 5; Dt 33), buscando situar em tal espaço o habitat original deste Deus.

Como este Deus se tornou um Deus na terra cultivável de Canaã, no espaço de emergência do antigo Israel? Acompanhada dessa pergunta surge outra: como um Deus ou o Deus se torna o elemento referencial na vida de uma sociedade? Em termos teológicos, a percepção de Deus se situa no momento primeiro da revelação. Os textos sagrados em geral (e a Bíblia em particular) estão perpassados pela ideia de um Deus que existe e se revela por meio das formas mais diversas. Palavras, visões, gestos simbólicos etc. são meios de condução da revelação. De uma forma bem geral, o 'profeta' é, na tradição monoteísta, a figura que realiza a intermediação. Aqui, nos limites deste artigo com um foco mais fenomenológico e histórico, não nos interessa descrever esse processo da revelação em si. Tomamos a expressão da experiência como um dado; esta emerge a partir da consciência de pessoas e na coletividade toma formas gestuais, orais e de escrita, passando a influenciar a identidade a partir do manejo de 
tradições em espaços privados e públicos. Aqui nos interessa não a origem última, mas o manejo social de expressões de fé de sujeitos distintos.

As tradições bíblicas buscam localizar a reverência ao Deus YHWH já nos tempos primaveris dos inícios da história do antigo Israel. Nos tempos da existência tribal ou pré-estatal, YHWH é afirmado como o "rei de Israel". A famosa resposta de Gideão em Jz 8,23 indica para isso: "Não eu nem meu filho [...] só YHWH dominará sobre vós”. É de se supor que a reverência a YHWH tenha sido expressão de identidades grupais ou tribais nos tempos iniciais da história de Israel. Eventualmente, contatos com grupos periféricos no deserto e talvez com alguma vivência no Egito tenham fomentado esse tipo de expressão de fé. Em todo caso, este YHWH dos tempos originários está vinculado com o âmbito de lutas, de batalhas e de guerras $(\mathrm{Jz} 5)$. Esta é uma função guerreira que provavelmente foi cooptada e fomentada quando essa divindade do deserto e da luta foi afirmada como divindade de referência na capital, Jerusalém, passando a integrar a tradição religiosa da cidade ao lado de tradições jebusitas ou cananeias locais.

A narrativa do traslado da arca da aliança para Jerusalém (2 Sm 6 , 12-19) afirma, provavelmente em termos míticos, essa incorporação. A informação textual em 2 Sm 8,17 e 20,25 de que Zadoque, o representante do clero jebusita, foi mantido na "lista dos oficiais de Davi" ao lado de Abiatar, o sacerdote das tribos, evidencia a integração das tradições relativas a um YHWH guerreiro do deserto nas representações religiosas da cidade. Isso possivelmente constituiu a base para a formatação de tradições religiosas que, mais tarde, culminaram na assim chamada 'teologia de Sião'. Com o manejo pelo sacerdócio citadino, YHWH passou a afirmado como uma espécie de Deus oficial da casa de Davi (2 Sm 7). Contudo, há que se ter presente que, na historiografia deuteronomista, encontram-se muitas retroprojeções mitificadoras a partir de tempos posteriores, de sorte que permanece difícil discernir claramente entre o que é histórico e o que é mítico. É provável que até o século VII a.C. não tenha havido culto exclusivo a YHWH no templo de Jerusalém, convivendo a sua representação com outras, como a da divindade terapêutica Neustã representada pela serpente de bronze (RIBEIRO, 2002), de Aserá, de Baal e da rainha dos céus (CORDEIRO, 2008). A polilatria provavelmente marcava 
o sistema religioso operado em Jerusalém até a centralização do culto na capital no século VII a.C. A partir da concentração no culto oficial exclusivo a YHWH no santuário central no período da reforma josiânica Deus passa a ser celebrado sem representação iconográfica, como o exige ou recomenda a normatização deuteronômica. Ao dizê-lo assim, cabe ressalvar que se trata de uma simplificação; no cotidiano histórico, os sujeitos de fé devem ter feito as sínteses mais diversas a partir de suas subjetividades.

A Bíblia hebraica assinala a construção do credo monoteísta e da correta monolatria javista como uma emergência no espaço do reino de Judá. Esse dado já carrega em si a perspectiva judaíta segundo a qual o conjunto das tradições do antigo Israel foi formatado no contexto do período tardio da monarquia e especialmente no pós-exílio. As informações sobre a fé em YHWH e suas formatações no reino do norte somente lograram recepção e espaço por meio do olhar sobre "o outro". A alteridade está incorporada no discurso oficial judaíta e em geral tende a ser pintados numa perspectiva negativa. Os inícios do reino do norte são apresentados como apostasia em relação ao culto oficial Jerusalém e de secessão em relação à casa de Davi (1Rs 11-12). Isso possivelmente já constitui parte da releitura. A base destas informações do relato provavelmente constitui parte da autocompreensão do reino do norte. A secessão em termos políticos é caracterizada em relação à casa de Davi, mas a projeção religiosa situa a constituição do reino do norte como resultado de uma luta de libertação em relação ao domínio egípcio. A tradição do êxodo é característica para as tradições do Israel setentrional, estando ausentes, por exemplo, nas palavras dos profetas do sul, podendo ser entendida como "mito de origem do Reino do Norte" (KESSLER, 2009, p. 123). A adoração a YHWH nos santuários oficiais de Betel e Dã possivelmente esteve associada ao uso de recursos iconográficos, em consonância com o entrono cultural cananeu. A fertilidade nos territórios setentrionais pode ter sido celebrada por meio de imagens como a do bezerro de ouro, mencionado polemicamente em Ex 32, com um exemplar encontrado em escavação arqueológica na região ao norte do Lago da Galileia. A imagem do bezerro estava associada com o culto a YHWH (OLIVEIRA, 2010). É provável também que o culto a Baal tenha feito parte das liturgias tradicionais no norte, em especial por ocasião das festas de colheita. 
Essas características religiosas no reino do norte dão o ensejo para a polêmica que é colocada na boca de dois personagens por serem fundadores da monolatria e do monoteísmo: Elias e Oseias. Em seus estudos sobre Elias, o exegeta alemão Frank Crüsemann (2001, p. 570) chega a ser enfático: "o que a Bíblia chama e apresenta como Deus não pode ser concebido sem Elias”. Em termos bíblicos, Elias é o ícone fundador do monoteísmo. Com sua figura, estão relacionadas as polêmicas mais contundentes contra os cultos de fertilidade, associadas a Baal (1Rs 18); o próprio reino do norte é vinculado essencialmente à idolatria, isto é, com o culto a outros deuses que não a YHWH, sendo os governantes considerados responsáveis por esse processo. Por definição intrínseca, o conceito de 'idolatria' já deve ser concebido a partir de uma posição considerada verdadeira ou oficial, portanto reflete perspectivas posteriores e oficiais. Por isso, as tradições de Elias marcadamente já carregam as releituras a partir do sul, obscurecendo a reconstrução da possível figura histórica de Elias, cuja existência histórica, contudo, não precisa ser descartada por completo, apesar de seus traços fortemente míticos.

No caso de Elias, e também do profeta Oseias, deve-se fazer a pergunta pelos atores sociais por trás dos conteúdos monolátricos. O americano Morton Smith (1971) sugere entender as polêmicas monolátricas como expressão de conflitos entre grupos proféticos ou sacerdotais adeptos de divindades e/ou santuários distintos. Conflitos de ordem econômica podem estar envolvidos nas polêmicas, na medida em que os cultos de fertilidade envolviam ofertas e dízimos oferecidos à divindade, mas concretamente entregues aos sacerdotes e ao santuário. Isso se torna especialmente evidente nas palavras polêmicas de Oseias, o qual reivindica dos israelitas que toda forma de oferta deve ser dirigida exclusivamente a YHWH, afirmando ser esse deus o doador de todas as dádivas de fertilidade do solo e dos ventres (Os 2). Quem se dirigir a outras divindades, especialmente a Baal, incorre na transgressão da idolatria ou da prostituição, como é recorrente na linguagem de Oseias. Contudo, não é necessário colocar sempre em primeiro plano os eventuais interesses econômicos em jogo nas disputas. Os protagonistas do movimento "somente YHWH", conforme é proposta por Smith, seguido por Lang $(1981,2002)$ e outros autores (ALBERTZ, 1992; DIETRICH; KLOPFENSTEIN, 1994), podem 
ter sido educadores populares, levitas ou profetas, convencidos de que sua perspectiva acerca do culto exclusivo a YHWH era a verdadeira. Eles realizavam as suas intervenções em eventos coletivos, protagonizando também disputas possíveis para que sua posição ganhasse aceitação, até por meio de processos catequéticos. Nas polêmicas, promoveu-se o deslocamento de elementos de uma representação de divindade para outra, no caso de Baal para YHWH. A partir dos conteúdos colocados na boca de Elias e especialmente de Oseias, YHWH é afirmado como divindade responsável também pelo âmbito da fertilidade. Com Elias e Oseias, YHWH é 'baalizado'.

A assunção do credo monoteísta ao status de credo oficial provavelmente somente se deu em Judá ao fim do século VIII a.C. Educadores populares de círculos levíticos devem ter protagonizado tais mensagens em eventos públicos nas vilas e nas cidades. A reforma de Ezequias (2 Rs 18), na medida de sua historicidade, pode ter sido um desses momentos catalizadores. Ante a constante ameaça da fragmentação e subjugação cultural e religiosa sob o domínio crescente dos assírios, houve em Judá uma conjugação de esforços no sentido de fortalecer a unidade e a identidade do reino em torno de um credo e de uma divindade única e representativa. No relato, o expurgo de formas cultuais indesejadas está vinculado com essa 'reforma'. É caso emblemático da destruição da imagem de Neustã e a retirada desse culto do âmbito do santuário oficial sem, contudo, conseguir suprimir a presença desta representação no imaginário popular (RIBEIRO, 2002). Para dentro, a reforma seleciona e expurga; para fora, projeta unidade, outorgando identidade nacional.

O momento de assunção poderia ser ainda mais marcante se, com a reforma de Ezequias, fosse vinculada a edição ou a sistematização do código da aliança (Ex 20,22-23,19). Na pesquisa mais recente, essa coleção de normas é alocada temporalmente para o fim do século VIII a.C, sendo considerada a coleção de leis mais antigas de Israel. Como já foi bem demonstrado, o centro estruturante da possível primeira coleção de leis de Israel/Judá é o primeiro mandamento, isto é, a exigência da adoração exclusiva a YHWH. Na sua obra A Torá, Crüsemann (2002) situa a sistematização das leis no período obscuro do governo de Manassés, na primeira metade do século VII a.C. Assim, o escrito permaneceria com 
uma perspectiva de resistência em meio a um contexto de reinserção da polilatria em Jerusalém sob o governo de Manassés. Contudo haveria que se considerar que a edição e o compromisso do povo para com um conjunto normativo de leis pressupõem a estrutura interventiva do Estado. $\mathrm{Na}$ cultura real do antigo Oriente, no qual Israel se acha incluído, 'códigos' de leis eram promulgados por governantes ao assumirem o poder ou em momentos de crise social ou nacional, como forma de propaganda oficial do próprio governante. Isso poderia ter sido o caso do código da aliança no contexto da reforma de Ezequias, embora, em termos literários, esta coleção de leis, assim como as demais do Pentateuco, não está vinculada com um governante concreto, mas literariamente é apresentada como revelação direta de Deus a Moisés no monte Sinai. A alocação mítica da dádiva das leis retira as mesmas de sua efetiva historicidade.

Como dominadores estrangeiros de plantão no Levante desde o século IX a.C., os assírios impuseram ao reino do norte o seu desmantelamento em termos políticos. Um rastro de destruição, morte e migrações forçadas foi a consequência da aniquilação da estrutura estatal no ano de 722 a.C. Vários contingentes populacionais lograram acolhida em espaços no reino de Judá, especialmente no entorno das maiores cidades, Jerusalém e Laquis. Essa agregação possivelmente contribuiu para um maior colorido religioso em Judá, especialmente durante o governo subalterno de Manassés.

O recuo dos assírios do Levante no fim da primeira metade do século VII a.C. possibilitou a reorganização do reino de Judá, cuja estrutura estatal permanecera praticamente intacta, apesar dos diversos e intensos sítios por parte dos assírios no contexto de suas campanhas militares regulares na região. Os projetos e as práticas expansionistas de Josias e sua reforma político-religiosa constituem o evento histórico mais importante desse período. Foi um momento em que, entre adesão e coerção, se constituíram traços marcantes da identidade do Israel do período. Uma parte das leis sociais do Deuteronômio espelha intentos reformistas, buscando constituir uma rede mínima de solidariedade entre os integrantes do povo, com olhar especial para as típicas personae miserae (órfãos, viúvas, estrangeiros, pobres), embora as normatizações não atinjam o grau de justiça esperado (BENNETT, 2002). Outra parte reflete a força coercitiva 
necessária para gravar a identidade religiosa-cultural pretendida, especial com o rechaço a formas de culto consideradas indesejadas a partir da perspectiva oficial.

O templo e o sacerdócio desempenharam um papel fundamental na execução da vontade governante, pois, na Antiguidade, santuários e seu corpo funcional faziam parte da estrutura estatal, inclusive no repasse dos diversos tipos de ofertas para atender aos interesses do Estado. A centralização do culto no templo em Jerusalém andou de mãos dadas com interdições de santuários no interior, impelindo os fiéis ao deslocamento à capital e à necessária submissão às intervenções coordenadas nos eventos festivos oficiais. No culto central, houve expurgos significativos naquele momento: santuários interioranos fechados, proibição do culto a Baal e a Ashera; retiradas de representações iconográficas (2 Rs 22-23). Memórias e tradições populares ou interioranas foram cooptadas e ressignificadas, especialmente a tradicional festa do pessah. Mas também a proposta oficial deve ter passado por ressignificações por parte dos populares participantes dos eventos. Afinal, os fiéis tecem a sua própria rede de sentidos, embora tantas vezes enredados nos fios oficiais.

A interdição de imagens para fins cultuais pode ter tido o seu nascedouro diferencial neste contexto do fim do século VII a.C. O "segundo mandamento bíblico" (Ex 20,4-6/ Dt 5,8-10), que constitui o núcleo legitimador da dimensão anicônica da fé em YHWH, pode ter tido neste momento o seu nascedouro como forma de resistência à dominação estrangeira. A tendência anicônica na cultura desse antigo Israel provavelmente emerge de um processo de convencimento de ordem filosófica de que a representação iconográfica restringe e aprisiona o conceito de Deus (REIMER, 2009, p. 69-90). Neste sentido, a tradição anicônica se coloca numa linha de resistência e fortalecimento da identidade interna. Outras medidas com relação à atividade profética e mântica, registradas no Deuteronômio, visaram a restringir abusos e controlar práticas inscritas no imaginário popular. O que emergiu da proposta da representação deuteronômica sobre YHWH poderia ser dito assim: YHWH é o Uno, soberano, só, masculino, encontrável no lugar que ele fizer habitar o seu nome (Jerusalém!?), responsável pela promoção da justiça em favor dos pobres e necessitados, mas também guardião da casa de Davi. 
A morte de Josias interrompeu o processo de expansão e unificação. A sua morte marca a renovada presença vigilante de novos poderes internacionais de plantão na região. O Egito procura barrar o avanço babilônico no horizonte oriental. Judá fica enquadrada nos limites das pressões externas. Resistências levam a deportações, exílios e, em 587/6 a.C., e, finalmente, à destruição da capital com todos os seus equipamentos estatais. Judá está em ruínas.

As ruínas de Jerusalém e de outras cidades de Judá significaram um grande desafio em termos teológicos. Em termos de representação religiosa, significou uma fragmentação da identidade nacional-estatal construída no século anterior. A crise do desmantelamento da estrutural estatal-nacional demandava por interpretação. Palavras (e vozes) de personagens proféticas foram auscultadas para o exercício interpretativo. O resultado é conhecido como 'teologia deuteronomista'. A história passada é lida à luz da Torá, isto é do núcleo do Deuteronômio. A adoração exclusiva a YHWH e a participação na prática na centralização cultual em Jerusalém foram eleitos como critérios fundamentais desta revisão histórica e teológica. Os artífices desse trabalho devem ser procurados fundamentalmente em pessoas e grupos sintonizados com o ideário da reforma josiânica e deuteronomista (RÖMER, 2008). Figuras proféticas como Elias, Oseias, Jeremias e Ezequiel são importantes o processo de construção do ideário do Uno só e masculino (PEREIRA, 2000, p. 88-102; REIMER, 2009, p. 91-102).

Vivências de parcelas do povo hebreu no exílio babilônico demandaram fortalecimento da identidade dos grupos desterrados. Embora nem todos estivessem submetidos à dura servidão, um grande desafio neste período foi a resistência à cultura religiosa dominante na Babilônia. Especialmente a cultura mítica mesopotâmica com suas narrativas de criação e ordenação do mundo, enaltecendo a figura de Marduc, o maioral no panteão divino, demandou a formatação de narrativas contraculturais próprias. A narrativa bíblica da criação $(\mathrm{Gn} 1,11)$ é resultado de um processo de recepção e transformação de elementos culturais e religiosos externos para a afirmação de uma representação religiosa interna: não Marduc, mas o Deus YHWH é o criador. Assim, pela ação de liderança dos grupos sacerdotais no exílio, foi agregada mais essa dimensão à representação de YHWH (ALBERTZ, 2001). 
Os grupos remanescentes na terra de Judá trataram de levar adiante a sua vida social, cultural e religiosa. Quando se trata de um tema como o da reforma político-religiosa de Josias, deve-se fazer a pergunta pela extensão ou alcance o projeto. É provável que setores ou segmentos sociais interioranos se mantivessem distanciados ou até alheios aos propósitos de centralização, seguindo antes os ditames de sua cultural tradicional. E a cultura popular judaico-cananeia era polilátrica. Assim, por exemplo, restos arqueológicos de um templo judaíta em Kuntillet Ajrud apresentam YHWH ladeado pela deusa Ashera, ambos sendo invocados para fins de bênção. É muito provável que elementos cultuais relativos a Baal, a Rainha dos Céus e a Neustã tenham tido o seu cultivo durante o período do exílio, marcando certa existência dispersiva da identidade monoteísta-nacional construída anteriormente por conjugação de vários esforços.

O período do pós-exílio constitui um novo momento de fortalecimento da ideia ou da concepção do Deus Uno. Esse é o momento histórico de consolidação de um ideário religioso construído no decurso de um longo período com distintos momentos. Contudo é no período do pós-exílio, durante o século V a.C. e inícios do século IV a.C. que a concepção deuteronômica formatada no fim do século VII a.C. recebe sua consolidação. Na época da reestruturação da comunidade judaica sob o governo dos persas, constituiu-se a província de Yehud e sobre o seu restrito território são elaborados os instrumentos de consolidação do ideário monoteísta e monolátrico: o templo, o sacerdócio e a formatação dos textos sagrados representativos desta comunidade (a Torá) (GERSTENBERGER, 2005). Novos conflitos são protagonizados no sentido da construção de uma identidade religiosa e de um conjunto de representações sobre o Deus de Israel, que se tornaram muito influentes nos tempos posteriores. Com as palavras do compilador do maior congresso mundial sobre o tema do monoteísmo, pode-se resumir o desenvolvimento desse ideário sobre o Deus YHWH da seguinte forma:

YHWH, na origem, era provavelmente um deus da montanha da região desértica do sul da Palestina, avançando para a função de deus pessoal de famílias israelitas; para o posto de deus nacional de Israel; para a função de deus da fertilidade da terra cultivável; para o deus dos céus provedor de direito e salvação; para o rei dos deuses; para criador do cosmo e dirigente da história; para o senhor sobre a morte e, por fim, para a função de juiz universal (DIETRICH, 1994, p. 23). 
No escopo deste texto, não é mais possível fazer a adequada apresentação dos eventos relativos à consolidação do ideário do Deus único e uno no período do pós-exílio. A ausência de um estado autônomo dá lugar à constituição de uma comunidade étnico-religiosa chefiada pelos sacerdotes a partir do templo. São muitos e incisivos os meandros deste processo nesse período. Aqui procuramos tão somente indicar alguns pontos marcantes da trajetória do processo da construção do Uno, uma representação angular no imaginário tanto ocidental quanto oriental.

\section{Referências}

\section{ALBERTZ, R. Religionsgeschichte Israels in Alttestamentlicher Zeit.}

Gottingen: Vandenhoeck \& Ruprecht, 1992. v. 1-2.

ALBERTZ, R. Die Exilszeit. 6. Jahrhundert v. Chr. Stuttgart; Berlin; Köln: Kohlhammer, 2001.

BENNETT, H. V. Injustice made legal: deuteronomic law and the plight of widow, strangers and orphans in ancient Israel. Grand Rapids; Cambridge: Eerdmans Publishing Company, 2002.

CORDEIRO, A. L.Asherah, a Deusa proibida. In: RICHTER, R. I. (Org.). Imaginários da divindade. São Leopoldo: Oikos; Goiânia: Ed. UCG, 2008. p. 25-48.

CRÜSEMANN, F. Elias e o surgimento do monoteísmo no antigo israel. Fragmentos de Cultura, Goiânia, v. 11, n. 5, p. 779-790, 2001.

CRÜSEMANN, F. A Torá: teologia e história social da lei do Antigo Testamento. Tradução de Haroldo Reimer. Petrópolis: Vozes, 2002.

DIETRICH, W. Einleitung. In: DIETRICH, W.; KLOPFENSTEIN, M. (Ed.). Ein Gott Allein? JHWH-Verehrung und Biblischer Monotheismus im Kontext der Israelitischen und Altorientalischen Religiongeschichte. Freiburg: Universitätsverlag; Göttingen: Vandenhoeck \& Ruprecht, 1994. p. 59-91.

GERSTENBERGER, E. S. Israel in der Perserzeit. 5. Und 4. Jahrhundert v. Chr. Stuttgart; Berlin; Köln: Kohlhammer, 2005. 
KESSLER, R. História social do antigo Israel. Tradução de Haroldo Reimer. São Paulo: Paulinas, 2009.

LANG, B. (Ed.). Der einzige Gott: die Geburt des Biblischen Monotheismus. Munique: Kosel Verlag, 1981.

LANG, B. Jahwe, der Biblische Gott: ein Porträt. Munique: Kosel Verlag, 2002. OLIVEIRA, T. C. dos S. A. Os Bezerros de Arão e Jeroboão: uma verificação da relação intertextual entre Ex 32,1-6 e 1Rs 12, 26-33. 2010. Tese (Doutorado em Teologia) - Pontifícia Universidade Católica do Rio de Janeiro, Rio de Janeiro, 2010.

OTTO, E. Jerusalem: die Geschichte der Heiligen Stadt. Stuttgart etc.: W. Kohlhammer, 1980.

PEREIRA, N. C. ... sem perder a ternura: Jamais! De homens mal-amados e mulheres prisioneiras no amor. Revista de Interpretação Bíblica Latino-Americana, Petrópolis, n. 37, p. 88-102, 2000.

REIMER, H. Inefável e sem forma: estudos sobre o monoteísmo hebraico. São Leopoldo: Oikos; Goiânia: Ed. UCG, 2009.

RIBEIRO, O. L. Nehushtan: pesquisa exegética, fenomenológica e histórico-social sobre a origem, a supressão e o suporte social do culto à serpente de bronze em Israel com base em Nm 21,4-9; Is 6,1-7 e 2 Rs 18,4. 2002. 128 f. Dissertação (Mestrado em Teologia) - Seminário Teológico Batista do Sul do Brasil, Rio de Janeiro, 2002.

RÖMER, T. A chamada história deuteronomista: introdução sociológica, histórica e literária. Tradução de Gentil Titon. Petrópolis: Vozes, 2008.

SMITH, M. Palestinian parties and politics that shaped the old testament. New York: Columbia University Press, 1971.

Recebido: 15/06/2011

Received: 06/15/2011

Aprovado: 20/10/2011

Approved: 10/20/2011 